\title{
ANALYZING THE FACTORS THAT AFFECT THE FINANCIAL REPORTING TIMELINESS OF MANUFACTURING COMPANIES LISTED IN INDONESIA STOCK EXCHANGE
}

\author{
Mulia Saputra, Indayani and Wilsen Yungata \\ Accounting Department, Syiah Kuala University, Banda Aceh, Indonesia \\ Email: mulia_1@unsyiah.ac.id; Indayani@unsyiah.ac.id;wilsen.yungnata14@gmail.com
}

\begin{abstract}
This study aims to find the empirical evidence about the factors that affect the timeliness of financial reporting in companies listed on the Indonesian Stock Exchange. The factors tested in this study are tax avoidance, audit opinion, and leverage ratio. The samples consist of 100 manufacturing companies listed on the Indonesian Stock Exchange from 2014-2017. The 400 total observed cases are comprised of annual reports from the selected companies are analyzed using logistic regression. The results of this study identified that audit opinion affects the timeliness of financial reporting, while tax avoidance and leverage have no effect on the timeliness of financial reporting of companies listed on the Indonesian Stock Exchange.
\end{abstract}

Keywords: Timeliness; Tax Avoidance; Audit Opinion; Leverage

\section{BAGAIMANA PENGHINDARAN PAJAK PERUSAHAAN, OPINI AUDIT DAN LEVERAGE MEMPENGARUHI KETEPATAN WAKTU PELAPORAN KEUANGAN}

\begin{abstract}
ABSTRAK. Penelitian ini bertujuan buat menciptakan fakta empiris tentang faktor- faktor yang mempengaruhi pada ketepatan waktu dari penyampaian laporan keuangan yang terdaftar pada bursa dilndonesia. Faktor- faktor yang diuji dalam riset ini adalah penghindaran pajak, opini audit, umur perusahaan, serta rasio leverage. Populasi dalam riset ini memakai 400 industri manufaktur yang terdaftar di Bursa Dampak Indonesia periode 2014- 2017 yang diambil dengan memakai purposive sampling. Faktor- faktor tersebut setelah itu diuji dengan memakai regresi logistik. Hasil riset mengenali kalau opini audit mempunyai pengaruh terhadap ketepatan waktu pada penyampaian laporan keuangan, sebaliknya penghindaran pajak, umur perusahaan, serta rasio leverage tidak mempunyai pengaruh pada ketepatan waktu penyampaian dari laporan keuangan industri manufaktur yang terdaftar di Bursa Indonesia.
\end{abstract}

Kata kunci: Ketepatan Waktu; Penghindaran Pajak; Opini Audit; Umur Perusahaan; Rasio Leverage.

\section{INTRODUCTION}

Due to increasing globalization, business activity and competition between companies are increasing rapidly. As a result, every company needs to be able to report audited financial statements on time because investors need more relevant and timely information. $\mathrm{Al}$ Daoud et al. and Fasting et al. (2014) state that timeliness of reporting is an important component of financial report quality. Meanwhile, Emeh and Ebimobowei (2013) explain that delays in disclosure of information can increase information asymmetry and uncertainty in investment decisions.

These days, people need information that is accurate and complete about a company's financial standing. Nadirsyah, Saputra, Djalil, \& Damayanti (2018) explain that information is the primary requirement of investors in the capital market. The information in the financial report can cover aspects such as the provision and delivery of financial information. Information on financial reports becomes useful for users only if the information is presented in a timely and accurate manner.

The issue of timeliness around financial reporting often arises because there are companies that delay reporting their financial statements by following the data obtained on the Indonesia Stock Exchange. Neraca (2018) reports that the Indonesia Stock Exchange imposes sanctions on companies that fail to submit audited financial statements by December 31 annually and also fail to pay penalty fees for the late submission. If companies are both late and fail to pay the fees, they have 91 calendar days after the financial reporting deadline to report and pay the fees to avoid suspension.

Neraca (2018) reports that at the end of October 2018, the Indonesian Stock Exchange imposed sanctions on the shares of 15 on the capital market issuers related to delays in submitting financial statements. In 2018, companies were required to submit an interim financial report on June 30 and refer to provision II.6.3 Rule Number IH: regarding sanctions. One of the 612 issuers was subjected to a Rp50 million fine and written warnings I and II for failing to submit audits for the first semester of 2018 by the specified deadline. While other 10 received written warnings because as of October 1, 2018 they had not submitted audited financial statements by theJune 30 deadline. In addition, 3 issuers received written warnings III and a fine of Rp150 million for failing to submit their mid-year financial reports and the audit as of October 1, 2018. Finally, BEI also imposed a written warning I to one issuer because it had not submitted the audited financial statements for the first semester of 2018 until October 1, 2018 (Neraca, 2018).

Even though some companies delay in reporting financial statements, the existence of these companies can still offer benefits to society, their region, and the country. One major source of Indonesia's income taxes come from companies. The prevalence of tax avoidance is one of the obstacles in optimizing tax revenue. 
According to Crabtree and Kubick (2014 in Brian \& Martani, 2014: 126) tax avoidance is typically concealed by a complicated and complex corporate tax structure to avoid the tax relevant authorities. This forces external auditors to be more thorough when conducting audits because the complicated tax structure can also be used to cover rent diversion. A more careful audit will increase the reliability of audited financial information, but on the other hand, the timeliness often suffers.

Audit opinions can also affect the timeliness of financial statements. Mulyadi (2002) explains that audit reports inform users about the auditor's process and the conclusions obtained during an audit or other attestation processes. The audit report consists of three paragraphs, namely: the opening paragraph, scope paragraph, and opinion paragraph. The audit opinion is expressed in the opinion paragraph which is part of the audit report (Mulyadi, 2002). The auditor who is in charge of examining companies' financial statements and workmanship.

Nurmiati (2016) explains that the leverage ratio has an influence on the timeliness of financial reporting. Van Horne and Wachowicz (2009: 206) state that leverage ratios are used to measure a company's ability to fulfill its short-term obligations. This ratio compares short-term obligations with available short-term resources to meet these obligations. Many insights can be obtained from this ratio regarding a company's current financial competencies and ability to remain competitive and consistent.

A company that has high financial leverage means that the company has a lot of debt from outside parties. This means that the company has a high financial risk due to financial distress caused by high debt. Schwartz and Soo's (1996) research shows that companies that experience financial difficulties tend to be less punctual in delivering their financial statements than companies that do not experience financial difficulties. Because financial difficulties are have negative implications, often struggling companies will not be timely in their financial reporting.

This research has implications for both the investors and the management. For the investor, this research will provide valuable information related to the influence of tax avoidance, audit opinion, and debt on the timeliness of financial reporting, so they can make the right investing decisions. For management, this research offers information related to the factors that influence tax avoidance, audit opinion, and debt on the timeliness of financial reporting

\section{METHOD}

Using a causal research method, this research applies cross-sectional studies as a time since the researcher uses financial reports from 2014-2017. The research data was obtained from the Indonesian Stock Exchange (IDX) website which provides information from as many as 120 manufacturing horizon companies from 2014-2017. Manufacturing companies were chosen because manufacturing companies consist of various industrial sub-sectors, so it can reflect the reaction of the capital market as a whole to preserve data homogeneity. One hundred companies were selected based on specific criteria (table.1). The data for this study are secondary data from the annual reports between 2014-2017.

\section{Table 1. Criteria of Sample}

\begin{tabular}{llc}
\hline No & \multicolumn{1}{c}{ Criteria } & Companies \\
\hline 1 & $\begin{array}{l}\text { Manufacturing Companies Listed on Indonesia } \\
\text { Stock Exchange 2014-2017 }\end{array}$ & 120 \\
2 & $\begin{array}{l}\text { Companies who were delisting } \\
3\end{array}$ & $\begin{array}{l}\text { Companies who do not have enough data } \\
\text { relating to the variables related to this study on } \\
\text { www.idx.co.id }\end{array}$ \\
\hline Total Companies & $(14)$ \\
\hline Years of observation & 100 \\
\hline Total observation sample & 4 \\
\hline & Source: Data Processed (2910)
\end{tabular}

\section{Analysis Method and Hypotheses Testing Design 1. Logistic Regression Analysis}

Logistic regression is a regression model that has been modified so its characteristics are no longer the same as a simple or multiple regression model. Therefore the determination of significance is statistically different. The hypothesis testing was done through multivariate analysis using logistic regression.

With this analysis technique, the authors do not conduct data normalization tests, because according to Ghozali, logistic regression does not require the assumption of normalization of the independent variables. Multivariate normal distribution assumption cannot be fulfilled. Thai is because the independent variable is a mixture of metric and non-matrix. Gujarati states that logistic regression also ignores the problem of heteroscedasticity, meaning that the dependent variable does not require homoscedasticity for each of its independent variables.

The multivariate testing model in this study uses logistic regression conducted with SPSS (Statistical Package for Social Science) program version 24. Based on previous research, analysis of testing with logistic regression should focus on the following factors (Singgih Santoso, 2001: 173):

\section{Feasibility Regression Model Test (Goodness-ofit)}

Before the regression model is analyzed, the regression model must meet several criteria assessing the feasibility of the model. Model feasibility is assessed by evaluating the overall fit model value. This test aims to determine whether the independent variables together can or cannot predict the dependent variable. The feasibility test of this model uses the Hosmer and Lemeshow Goodness-of-Fit Test. This model tests the null hypothesis that empirical data is suitable or in accordance with the model. If the value of Hosmer and Lemeshow Goodness of Fit Test $\leq 0.05$ then the $\mathrm{H} 0$ is 
rejected. This means that there were significant differences between the model and the value of the observations. Whereas if the value of Hosmer and Lemeshow Goodness of Fit Test $>0.05$ then $\mathrm{H} 0$ cannot be rejected.

\section{Overall Model Fit test}

The next step from this model is the overall model fit test. With the model fit test, testing is conducted by comparing the value between -2 Log-Likelihood (-2LL) at the beginning $($ Block Number $=0)$ with the value of -2 Log-Likelihood $(-2 \mathrm{LL})$ at the end (Block Number $=1)$. The reduction in value between the initial -2LL and $-2 \mathrm{LL}$ in the next step indicates that the hypothesized model fits with the data (Ghozali (2001)). Log-Likelihood in logistic regression is similar to the notion of "sum of squared errors" in the regression model so that the decrease in LogLikelihood shows a positive regression model.

\section{Regression Coefficient test}

Regression coefficient testing is done to test how much all the independent variables included in the model influence the dependent variable. Logistic regression models are used to test the following hypotheses:

$$
\begin{aligned}
\mathrm{LN} \frac{\mathrm{TIME}}{1-\mathrm{TIME}} & =\mathrm{a}+\mathrm{b}_{1}(\text { CashETR })+\mathrm{b}_{2}(\mathrm{AO})+\mathrm{b}_{3}(\mathrm{AGE})+ \\
\mathrm{b}_{4}(\mathrm{DER}) & +
\end{aligned}
$$

Description:

$$
\begin{array}{ll}
\text { TIME } & =\text { Timeliness of financial reporting } \\
\mathrm{a} & =\text { Constant } \\
\mathrm{b}_{1}, \mathrm{~b}_{2}, \mathrm{~b}_{3} \text { and } \mathrm{b}_{4} & =\text { Coefficient Regression } \\
\text { CashETR } & =\text { Tax Avoidance } \\
\text { AO } & =\text { Audit Opinion } \\
\text { AGE } & =\text { Company Age } \\
\text { DER } & =\text { Leverage Ratio }
\end{array}
$$

\section{Hypothesis Testing}

The regression coefficient is tested to find out how much influence each independent variable has on the dependent variable. The regression coefficient can be determined through the Wald statistic when the probability value (sig) is compared with $\alpha$. The decision to reject or accept Ho is based on a significant level $(\alpha)$ of $5 \%$ with the following criteria: If asymptotic signature $>\alpha$, then Ho is accepted. This means that Ha is rejected or the hypothesis that the independent variable influences the dependent variable is rejected. If asymptotic significance is $<\alpha$, then Ho is rejected. This means that $\mathrm{Ha}$ is accepted or a hypothesis stating that the independent variable influences the dependent variable is accepted. Thus, the hypotheses test uses regression coefficients and the relationship between these variables.

\section{RESULTS AND DISCUSSION}

This study was conducted to examine how tax avoidance, audit opinion, and leverage affected the timeliness of financial reporting of manufacturing companies listed on the Indonesian stock exchange from
2014-2017. In this study, descriptive statistics explain that the value of average tax avoidance (CashETR) is 0.2299, which means that the average value of the sample companies is $22.99 \%$ and the standard deviation of tax avoidance is 1.01368. Meanwhile, the lowest value of the overall tax avoidance observed is -8.82 or $-882 \%$ experienced by PT Sumalindo Lestari Jaya in 2015. Whereas the highest value of 10.17 or $1,017 \%$ was experienced by PT Malindo Feedmil in 2017. The lowest value of audit opinion (AO) is 0 meaning the company received an audit opinion other than an unqualified opinion. While the highest value of 1 means that the company received an unqualified audit opinion as well. The average value of leverage ratio (DER) is 1.6123 with a standard deviation of 9.65936 . The lowest value of all observations for the variable leverage ratio is experienced by PT Schering Plough Indonesia in 2014 worth -31.18 or $-3,118 \%$. The highest value is 162.19 or $16,219 \%$ in 2016 experienced by PT Eterindo Wahanatama.The lowest value of timeliness of financial reporting is 0 meaning the company did not submit their financial report in a timely manner. While the highest value is 1 means the company submitted their financial report on time. A total of 367 , or $91.8 \%$, of the examined companies submitted their financial report on time. Meanwhile, 33 companies, or $8.3 \%$, of the examined companies did not submit their reports on time.

\section{Data Analysis and Statistic}

The steps used in analyzing the results of logistic regression include assessing the feasibility of the regression model (goodness-of-fit test), assessing the overall model (overall model fit), and assessing the accuracy of the regression classification (overall classification table). Hosmer and Lemeshow's Goodness-of-Fit Test shows that if Chi-square 20.484 and the value of sig $=0.009<$ $5 \%$ is obtained, then $\mathrm{H} 1$ is accepted. This means that the hypothesis model does not fit the data. In other words, there might be a significant difference between the model and its observational value. The Model Fit Test shows when the value of $-2 \operatorname{LogL}$ Block Number $=0$ is 227.867 then there is a decrease in the value of $-2 \operatorname{LogL}$ block number $=1$ to 215.687 , the magnitude of the decrease of $-2 \log \mathrm{L}=12.180>7.81(\mathrm{X} 2(0.04 .4)=7.81)$ then it can be concluded that the independent variable can improve the logistic regression model.

The Cox \& Snell R Square and Nagelkerke R Square Test both determine the effect of independent variables on the dependent variables simultaneously. This test will establish the degree to which corporate tax avoidance, audit opinion, and leverage affect the timeliness of financial reporting. The Nagelkerke $\mathrm{R} 2$ value $=0.069$ or $6.9 \%$ meaning the magnitude of the effect of X1, X2, X3 on $\mathrm{Y}$ simultaneously is $6.9 \%$.

\section{Hypothesis Testing}

The results of the hypothesis testing research on tax avoidance show that the regression coefficient is -0.261 and 
the significance value is 0.079 (more than 0.05) meaning $\mathrm{H} 2$ is rejected. Thus, the results of statistical calculations show that tax avoidance does not significantly influence the timeliness of financial reporting. The results of this study do not support hypothesis 1 . However, The results on audit opinion show that the regression coefficient is 3.342 and the significance value is 0.008 (less than 0.05 ) so $\mathrm{H} 2$ cannot be rejected. Thus, the results show that audit opinion influences the timeliness of financial reporting. The results of this study support hypothesis 2 . The final test of hypothesis 3 on leverage shows that the regression coefficient is -0.02 and the significance value is 0.07 (more than 0.05$)$ so $\mathrm{H} 3$ is rejected. Thus, the results show that leverage does not significantly influence the timeliness of financial reporting. The results of this study do not support hypothesis 5 . In accordance with the hypothesis, this study shows that of the variables examined in this study that might influence the timeliness of manufacturing companies' financial reporting, audit opinion was the primary factor. Meanwhile, the variables of tax avoidance and leverage do not significantly influence the timeliness of financial reporting.

From the result, the following regression equation is:

$$
\begin{aligned}
\mathrm{LN} \frac{\mathrm{TIME}}{1-\mathrm{TIME}}= & -0.684-0.261(\mathrm{CashETR})+3.342(\mathrm{AO})- \\
& 0.002(\mathrm{AGE})-0.02(\mathrm{DER})
\end{aligned}
$$

The results of the above research find empirical evidence that manufacturing companies listed on the Indonesian Stock Exchange (IDX) still have a tendency to not experience the timeliness of financial reporting. Based on the results, 33 manufacturing companies ( $8.25 \%$ ) have a financial reporting timeliness index of 0 , which means the company has previously failed to submit financial reports on time, while the remaining $91.75 \%$ or 367 companies have a history of timely financial reporting. Companies that are not imely with their financial reporting should be reprimanded or given strict sanctions to discourage future lateness.

The timeliness of financial reporting influences the activities of actors in the stock market because the timeliness will affect stock prices and investors' decisions in maximizing the value of their investments. If a company submits its financial reporting on time, it has more time to maximize the incoming investment opportunities. The results show that tax avoidance does not affect the timeliness of financial reporting. Regardless of whether a company commits tax avoidance or not, the timeliness of their financial reporting is not affected. This is because most companies have the same goal, which is to provide information in accordance with public demand. Furthermore, the regulations requiring that companies listed on the Indonesian Stock Exchange submit their financial statements in a timely manner, makes the company more timely, in order to avoid the sanctions or fines associated with lateness.
The results of this study are consistent with the results of research by Astriyana, et al. (2016) which suggests that tax avoidance has no effect on the timeliness of financial reporting, which means that the greater the tax avoidance by the company or the less tax avoidance carried out does not affect the timeliness of financial reporting.

An audit opinion is an assessment by an independent auditor on a company's fairness and level of compliance with regulations when producing financial statements. Based on this research, the audit opinion has an influence on the timeliness of financial statement submissions. This result is in line with results of research conducted by Carslaw and Kaplan in Hilmi \& Ali (2008), where the delay in the companies' financial statement submissions was influenced by the opinion of public accountants to companies and companies that do not receive unqualified opinion experience longer audit delays. Research conducted by Whittered in Hilmi \& Ali (2008) also explains that financial statements that provide qualified opinions and recommendations cause longer delays.

Significant test results prove that this hypothesis is rejected, which means leverage does not affect the timeliness of financial reporting. Leverage refers to how far a company depends on creditors in financing the company's assets. Hilmi and Ali (2008) state that the leverage ratio measures the level of assets of a company that has been financed through debt. Financial leverage can be interpreted as the use of assets and source funds by companies that have fixed costs in order to increase the potential shareholder returns. The result of this study is consistent with research conducted by Hilmi and Ali (2008) in their research which suggested that the debt to equity ratio does not significantly influence the accuracy of published financial statements. The accuracy of funds allocated from debt that pushes the position of debt owed by the company, however, this is certainly not a barrier for companies to publish their financial statements on time. In this case, the timeliness of the publication of financial statements is more caused by a number of other variables not examined in this research model.

\section{CONCLUSION}

This study examines factors such as tax avoidance, audit opinion, and leverage ratio. Data from 100 manufacturing companies listed on the Indonesian Stock Exchange between 2014 to 2017 were analyzed in this study. The results indicate that audit opinion affects the timeliness of financial reporting, while tax avoidance and leverage ratio have no effect on the timeliness of financial reporting of the examined companies. This study has several limitations that can be considered for further research in order to achieve better results in the future. This research was only conducted on manufacturing companies listed on the Indonesian Stock Exchange with various predetermined criteria so that they cannot be generalized to all companies 
listed on the Indonesian Stock Exchange. There are still other independent factors that can influence the timeliness of financial reporting, such as gearing ratio, profitability ratio, company size, and others.

The suggestions that can be given to firm management it is better to analyze the timeliness of the company's financial reporting to anticipate potential reprimands or sanctions if the company ignores it. Timeliness of financial reporting means a company has complied in reporting its financial statements in a timely manner according to established deadlines. Companies should try to maintain their viability to compete with strong competitors as a business consideration for investors looking for experience, age, and ability. For the public, many parties will benefit from the timeliness of financial reporting, especially investors who use financial statements .

\section{REFERENCES}

Al Daoud, K.A. (2014). The Timeliness of Financial Reporting among Jordanian Companies: Do Company and Board Characteristics, and Audit Opinion Matter?. Asian Social Science, 10, (13), 191-201.

Astriyana, G., Amrizal., Sari, M.N. \& Hasanah, N. (2016). Pengaruh Kualitas Audit, Penghindaran Pajak Dan Konservatisme Akuntansi Terhadap Timeliness Reporting. (Studi Empiris pada Perusahaan Perbankan yang terdaftardi Bursa Efek Indonesia Tahun2011-2015). Seminar Nasional dan The 3rd Call for Syariah Paper. ISSN 2460-0784.

Astuti, C.D. (2007). Factors That Affect the Timeliness of Financial Reporting. Journal of Information, Taxation, Accounting and Public Finance, 2, (1), $27-42$.

Astuti, Y.P. (2012). The Influence of Perception of Tax Justice on Behavior of Compliance of Corporate Taxpayers in Indonesia. Jakarta: University of Indonesia Postgraduate Program.

Brian, I. \& Martani, D. (2014). Analysis of the Effects of Tax Avoidance and Family Ownership on the Time of Announcement of the Company's Annual Financial Statements. Finance and Bank Journal. $16,(2), 125-139$.
James, C \& Jerry I Porras. (2001). Build to Last: Tradisi Sukses Perusahaan-Perusahaan Visioner. Jakarta: Erlangga.

Emeh, Y. \& Ebimobowei, A. (2013). Audit Committee And Timeliness Of Financial Reports: Empirical Evidence From Nigeria. Journal of Economics and Sustainable Development. 4, (20), 14-25.

Ghozali, I. (2013). Aplikasi Analisis Multivariate dengan Program SPSS. Edisi Ketujuh. Semarang: Universitas Diponegoro.

Hilmi, U. \& Ali, S. (2008). Analisis Faktor-Faktor yang Mempengaruhi Ketepatan Waktu Penyampaian Laporan Keuangan (Studi Empiris pada Perusahaan-Perusahaan yang Terdaftar di BEJ). Simposium Nasional Akuntansi XI Ikatan Akuntan Indonesia.Kasmir. (2014). Analisis Laporan Keuangan. Edisi Satu. Cetakan Ketuju. Jakarta: PT Raja Grafindo Persada.

Mulyadi. (2002). Auditing, Edisi enam. Jakarta: Salemba Empat.

Nadirsyah, S., Djalil, M.A. \& Damayanti, R. (2018). Tax amnesty establishment, abnormal return and trading volume activity in Indonesia stock exchange. Journal of Applied Economic Sciences, 13, (4), 1101-1109.

Nurmiati. (2016). Faktor-Faktor Yang Mempengaruhi Ketepatan Waktu Pelaporan Keuangan. Jurnal Ekonomi Dan Manajemen, 13, (2), 166-182.

Neraca.co.id. (2018). IDX Imposes Sanctions Against 15 Issuers - Late Financial Statements. ttp://www. neraca.co.id/), accessed May 8, 2019.

Schwartz, K. \& B. Soo. (1996). Evidence of Regulatory Non-complience with SEC Disclosure Rules on Auditor Changes. The Accounting Review, 4: 555572.

Sugiyono. (2010). Metode Penelitian Pendidikan Pendekatan Kuantitatif, kualitatif, dan $R \& D$. Bandung: CV. Alfabeta.

Sugiyono. (2013). Metode Penelitian Kuantitatif, Kualitatif dan R\&D. Bandung: CV. Alfabeta. 